Environment Conservation Journal 15(1\&2) 135-148, 2014

ISSN 0972-3099 (Print) 2278-5124 (Online)

Abstracted and Indexed

\title{
Evaluation of physico-chemical quality of groundwater in the surroundings of Valiathura sewage farm in Thiruvananthapuram District, Kerala, South India
}

\author{
Jainy Varghese $\bowtie$ and D.S. Jaya
}

Received:11.09.2013

Revised: 22.01.2014

Accepted: 19.02.2014

\begin{abstract}
The present study was conducted to determine the changes in the physico-chemical characteristics of the groundwater in the surroundings of the sewage farm in Valiathura, Thiruvananthpuram district, Kerala. For this, 42 groundwater samples (29 dug wells and 13 bore wells) were collected bimonthly from the study area during the period January to December 2010 covering pre-monsoon, monsoon and post-monsoon seasons and the major physico-chemical parameters were analysed. The values recorded for parameters such as total alkalinity $(330 \mathrm{mg} / \mathrm{l})$, potassium $(63.40 \mathrm{mg} / \mathrm{l})$, magnesium $(52.39 \mathrm{mg} / \mathrm{l})$ and phosphates $(4.71 \mathrm{mg} / \mathrm{l}$ in dug wells at some stations exceeded the desirable limits for drinking water quality prescribed by WHO and BIS standards. The Sodium Adsorption Ratio (0.20 - 6.33), Percent sodium (8.54 - 71.83$)$ and Permeability Index values $(48.07$ - 119.35) showed that all the groundwater samples in the study area were suitable for irrigation purposes. The study revealed that about $31 \%$ of the dug wells adjacent to the sewage farm and Parvathy Puthen Ar canal were moderately contaminated and consumption of water from these wells may lead to various health problems in residents. As nutrients like phosphates, sodium, potassium, magnesium were high in well water samples and prolonged consumption of nutrients enriched well water may cause health problems such as high blood pressure, bowel cancer (due to phosphates), cardiovascular diseases (due to sodium and magnesium), renal diseases (due to sodium and potassium).Therefore effective management measures should be taken to protect the groundwater sources in Valiathura area.
\end{abstract}

Key words: correlation analysis, groundwater quality, irrigational quality, physico-chemical parameter, sewage farm

\section{Introduction}

Groundwater is an important renewable resource in the earth. It is the major source of water supply for domestic, irrigational and industrial purposes. About one third of the world's population use groundwater for drinking (UNEP, 1999). The quality of groundwater depends on the several factors like topography, rainfall, soil texture, soil permeability, depth to groundwater level and aquifer characteristics. Today the accelerated pace of urbanisation, industrialisation and population explosion increased the demand for water sources and exerted more and more pressure on the groundwater bodies (Sharma and Kaur, 1996; Kumar, 2002). Natural and anthropogenic activities created major stress on the groundwater sources in the world. High population density along the coastal areas resulting over abstraction of groundwater through dug wells and resulting saline

\section{Author's Address}

Department of Environmental Sciences, University of Kerala, Kariavattom Campus, Thiruvananthapuram, Kerala

Email: jainy.env@gmail.com water intrusion problem. Human groundwater contamination can be related to sewage disposal system, disposal of solid and liquid wastes, fertiliser application, animal wastes, improperly constructed septic tank system, latrine pits, land application of sludge and partially treated waste water etc. Among these the use of sewage (waste water) for irrigation is one of the important sources of groundwater pollution. The impact of sewage irrigation on groundwater quality was studied by various authors (Quin, 1978; Raju et al. 1991; Sial et al. 2005; Mahmood and Maqbool, 2006; Gwenzi and Munondo, 2008; Meena et al. 2010 and Sheet, 2012) in different parts of the world. Omana (2002) carried out a preliminary study on physicochemical and bacteriological characteristics of water from four selected wells subjected to sewage pollution in Thiruvananthapuram city and reported that the well water was contaminated. Chithra (2010) studied the impacts of sewage irrigation on grass cultivation in the sewage farm. Previous studies conducted by Varghese and Jaya (2009) on 
the bacteriological quality of groundwater sources around the sewage farm showed that the most of the groundwater sources are with bacteriological contamination. The quality of groundwater sources in the surroundings of the sewage farm at Valiathura is under threat due to the seepage of waste water from septic tanks and latrine pits, polluted Parvathy Puthen Ar canal and saline water intrusion (Omana, 2002). The people living in this area directly dependent on the available groundwater for their daily domestic and agriculture needs. The review of literature showed that there were no detailed studies regarding the drinking and irrigational quality of water from the groundwater sources in the surroundings of sewage farm. Therefore the major objective of this study was to characterize the physico-chemical quality of dug wells and bore wells in the residential areas near the sewage farm in Valiathura, Thiruvananthapuram district.

\section{Material and methods}

\section{Study area}

The study was conducted in groundwater sources (dug wells and bore wells) in the surroundings of the sewage farm at Valiathura in the coastal stretch of Thiruvananthapuram District, Kerala. The Survey of India (SOI) Toposheet 58D/15/NE and $58 \mathrm{D} / 15 / \mathrm{SE}$ of $1: 25,000$ scale have been used for the preparation of location map of the study area. The study area lies between longitude $76^{\circ} 54^{\prime} 51^{\prime \prime}$ E to $76^{\circ} 57^{\prime} 33^{\prime \prime} \mathrm{E}$ and latitude $8^{\circ} 26^{\prime} 26^{\prime \prime} \mathrm{N}$ to $8^{\circ} 29^{\prime}$ $29^{\prime \prime} \mathrm{N}$. The location map of the study area is shown in Fig.1. Valiathura sewage farm comprises an area of 108 acres and is maintained by the Dairy Development Department, Kerala state where grass cultivation is done. The main grass species cultivated here are Para Grass (Brachiaria mutica) and Hybrid Napier (Pennisetum purpureum). It has a capacity to handle 80 million litres of sewage per day (Chithra, 2010).
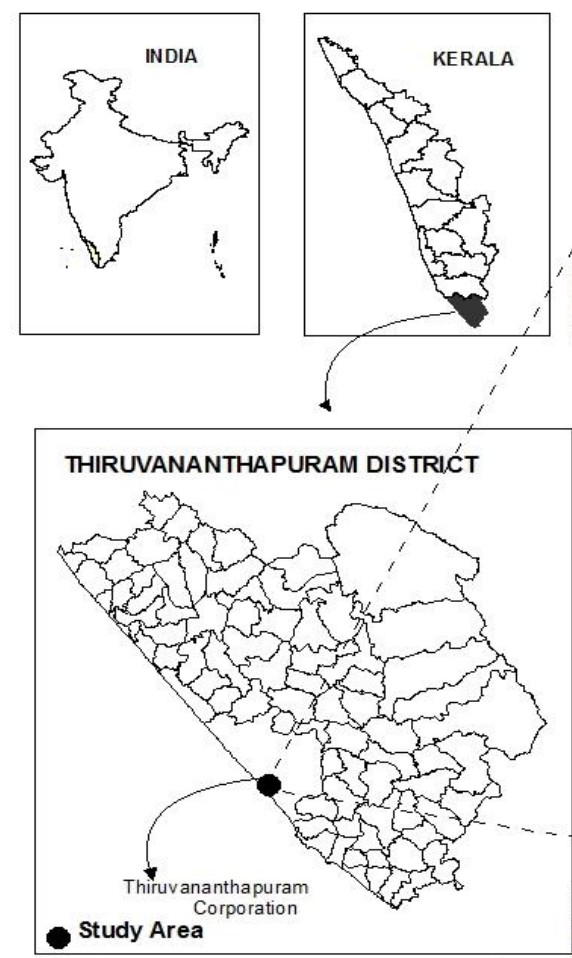

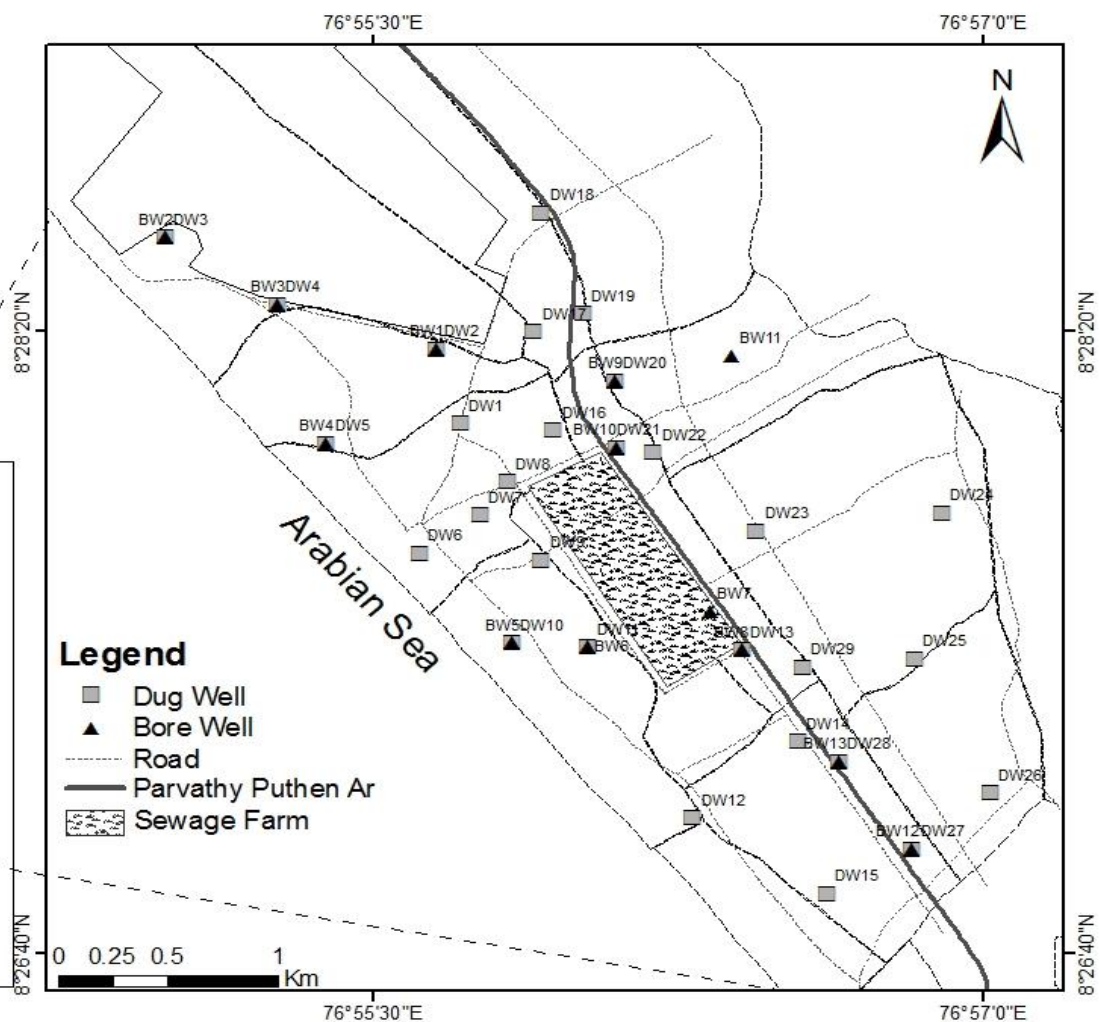

Fig. 1 Location map of study area 
Sample collection and Physico-chemical analysis Groundwater samples $(n=42)$ were collected bimonthly from the residential area around the sewage farm during the period January to December 2010 covering three seasons viz, premonsoon, monsoon and post-monsoon. Depth to Water level in the study area was measured by using graduated tape before collecting the water samples from the study area. The water samples were collected on polyethylene bottles prewashed with dilute hydrochloric acid and rinsed with the water sample before filling them to the required capacity.The collected dug well samples (DW1DW29) and bore well samples (BW1-BW13) were analysed to determine various physico-chemical parameters using the standard procedures described in APHA (1995), Trivedi and Goel (1986) and Saxena (1998). Temperature, $\mathrm{pH}$ and electrical conductivity of water samples were measured immediately after sampling using thermometer, $\mathrm{pH}$ meter (Systronics, India) and conductivity meter (Systronics model, $601 \mathrm{E}$ ) respectively. Correlation analysis was done using Statistical Package for Social Sciences (SPSS, version 17). Chloro Alkaline Indices (CAI) can be calculated using the equation as suggested by Schoeller (1977) as,

$$
\begin{gathered}
\text { CAI } 1=\frac{\mathrm{Cl}^{-}-\left(\mathrm{Na}^{+}+\mathrm{K}^{+}\right)}{\mathrm{Cl}^{-}} \\
\text {CAI } 2=\frac{\mathrm{Cl}^{-}-\left(\mathrm{Na}^{+}+\mathrm{K}^{+}\right)}{\mathrm{SO}_{4}^{2-}+\mathrm{HCO}_{3}^{-}+\mathrm{CO}_{3}^{2-}+\mathrm{NO}_{3}^{-}}
\end{gathered}
$$

\section{Textural analysis of Soil}

Texture of the soil samples were determined by using International Pipette analysis (Jackson, 1967). For this, soil samples were collected from the 31 sampling stations from the study area.

\section{Irrigational Quality of Groundwater}

To analyse the irrigational quality of groundwater the parameters such as Sodium Adsorption Ratio, Percent Sodium, Residual Sodium Carbonate, Magnesium Ratio, Permeability Index, Kelley's Ratio (Raghunath, 1987; Todd, 2001; Eaton, 1950; Pandian and Sankar, 2007; Kelley, 1946 and Doneen, 1964) were calculated. All the concentrations are expressed in meq/l.

\section{Sodium Adsorption Ratio (SAR)}

$$
\text { SAR }=\frac{\mathrm{Na}^{+}}{\sqrt{\frac{\mathrm{Ca}^{2+}+\mathrm{Mg}^{2+}}{2}}}
$$

Percent Sodium (\%Na)

$$
\% \mathbf{N a}=\frac{\mathrm{Na}^{+}+\mathrm{K}^{+}}{\mathrm{Ca}^{2+}+\mathrm{Mg}^{2+}+\mathrm{Na}^{+}+\mathrm{K}^{+}} \times \mathbf{1 0 0}
$$

Residual Sodium Carbonate (RSC)

$$
\mathrm{RSC}=\left(\mathrm{HCO}_{3}^{-}-\mathrm{CO}_{3}^{2-}\right)-\left(\mathrm{Ca}^{2+}+\mathrm{Mg}^{2+}\right)
$$

Magnesium Ratio (MR)

$$
\mathbf{M R}=\frac{\mathrm{Mg}^{2+} \times 100}{\mathbf{C a}^{2+}+\mathrm{Mg}^{2+}}
$$

Permeability Index (PI)

$$
\mathbf{P I}=\frac{\mathrm{Na}^{+}+\sqrt{\mathrm{HCO}_{3}^{-}}}{\mathrm{Ca}^{2+}+\mathrm{Mg}^{2+}+\mathrm{Na}^{+}}
$$

Kelley's Ratio (KR)

$$
\mathbf{K R}=\frac{\mathrm{Na}^{+}}{\mathrm{Ca}^{2+}+\mathrm{Mg}^{2+}}
$$

\section{Results and Discussion \\ Groundwater level}

During pre-monsoon, monsoon and post-monsoon seasons, the depth to water level in the study area ranges from 1.24 to $4.80 \mathrm{~m} \mathrm{bgl}$ (below ground level) $(\mathrm{avg}=2.63), 0.91$ to $4.60 \mathrm{~m} \mathrm{bgl}(\mathrm{avg}=2.45)$ and 0.67 to $4.42 \mathrm{~m} \mathrm{bgl} \mathrm{(avg=2.24)} \mathrm{respectively.} \mathrm{The}$ study showed that depth to water level was seasonally varied during the study period.

Physico-chemical characteristics of groundwater The analytical results of physico-chemical parameters of dug well and bore well water in the study area are given in Table 1.The temperature of shallow groundwater is controlled to a considerable extent by the atmospheric temperature (Karanth, 1987). The average temperature of groundwater samples in the study area were found as $29.61^{\circ} \mathrm{C}$, $28.90^{\circ} \mathrm{C}$ and $28.42^{\circ} \mathrm{C}$ during pre-monsoon, monsoon and post-monsoon seasons respectively. The hydrogen ion concentration $(\mathrm{pH})$ of samples in pre-monsoon varied from 5.42 to 7.16 (Avg=6.37) and in monsoon, it varied from 5.75 to 8.26 $(\mathrm{Avg}=7.02)$.The $\mathrm{pH}$ of groundwater samples during post-monsoon season ranged between 5.58 and 7.34 , with an average value of 6.71 . 
The $\mathrm{pH}$ of the groundwater samples showed acidic to alkaline nature during the study periods. The $\mathrm{pH}$ of groundwater commonly ranges from 6 to 8.5 (Ramakrishnan, 1998). In the present study about $45 \%$ of dug wells and all bore wells samples recorded acidic $\mathrm{pH}(<6.5)$ during pre-monsoon season and this was below the desirable limit of drinking water quality standards (BIS, 1991). Conductivity is a measure of the ability of water sample to carry an electric current (Rajvaidya and Markandy, 2005). Electrical conductivity of groundwater samples ranged between $144.50 \mu \mathrm{S} / \mathrm{cm}$ and $1015 \mu \mathrm{S} / \mathrm{cm}$ with an average of $499.66 \mu \mathrm{S} / \mathrm{cm}$ during pre-monsoon season. Lowest value $(144.50 \mu \mathrm{S} / \mathrm{cm})$ was reported at DW25 and higher value $(1015 \mu \mathrm{S} / \mathrm{cm})$ was recorded at DW29. In monsoon season, electrical conductivity of water samples ranged from $165.15 \mu \mathrm{S} / \mathrm{cm}$ to $1578 \mu \mathrm{S} / \mathrm{cm}$. The minimum and maximum value was observed at BW2 and DW29 respectively.But on post-monsoon season, the highest electrical conductivity value $(1228.50 \mu \mathrm{S} / \mathrm{cm})$ was recorded at DW29, and the lowest value $(171.8 \mu \mathrm{S} / \mathrm{cm})$ was recorded at DW23. The water quality is usually judged on the basis of electrical conductivity value (Venkateswarlu, 1996) as excellent (less than $250 \mu \mathrm{S} / \mathrm{cm}$ ); good (250-750 $\mu \mathrm{S} / \mathrm{cm}) ;$ permissible $(750-2000 \mu \mathrm{S} / \mathrm{cm})$; needs treatment (2000-3000 $\mu \mathrm{S} / \mathrm{cm})$; and unsuitable for most purposes $(>3000 \mu \mathrm{S} / \mathrm{cm})$. Based on this, the present study revealed that the majority of groundwater samples have high dissolved ions and they come under excellent to permissible category.Turbidity means the clarity of water. The turbidity values in ground water samples varied from $0.1-6.35$ NTU during pre-monsoon, 0.1- 5.7 NTU during monsoon and 0.55- 4.65 NTU postmonsoon season. According to WHO standards, the desirable limit of turbidity in drinking water is 5 NTU. The turbidity values of DW5 and BW7 exceeded the desirable standard limit during premonsoon and monsoon seasons respectively. This may be due to the dissolution of silt and clay from the soil in the study area.The total dissolved solids (TDS) means the total concentration of dissolved minerals (salts) in water. The average concentration of total solids in groundwater samples were observed as $543.45 \mathrm{mg} / \mathrm{l}$ (pre-monsoon),460.49 $\mathrm{mg} / \mathrm{l}$ (monsoon), $329.10 \mathrm{mg} / \mathrm{l}$ (post-monsoon) and total suspended solids (TSS) were recorded as $233.86 \mathrm{mg} / \mathrm{l}, 174.61 \mathrm{mg} / \mathrm{l}$ and $85.25 \mathrm{mg} / \mathrm{l}$ during pre-monsoon, monsoon and post-monsoon respectively. The concentration of TDS varies from 91 to $657 \mathrm{mg} / \mathrm{l}$ in pre-monsoon samples, 88.50 to $815 \mathrm{mg} / \mathrm{l}$ in monsoon samples and 75 to $609 \mathrm{mg} / \mathrm{l}$ in post-monsoon samples. According to WHO standards, the desirable limit of TDS for drinking water is $500 \mathrm{mg} / \mathrm{l}$. The study showed that TDS content of all the water samples except station at DW19 (monsoon) and DW29 (monsoon and postmonsoon) were within the desirable limit.Total alkalinity of water is due to the presence of carbonates, bicarbonates and hydroxide ions. The minimum and maximum concentration of total alkalinity in groundwater samples were $40 \mathrm{mg} / \mathrm{l}$ (DW5) and $240 \mathrm{mg} / \mathrm{l}$ (DW25) in pre-monsoon season. During monsoon season total alkalinity of groundwater samples ranges from $40 \mathrm{mg} / \mathrm{l}$ to 250 $\mathrm{mg} / \mathrm{l}$ (DW29) whereas in post-monsoon season it ranged between $70 \mathrm{mg} / \mathrm{l}$ (BW11) and $330 \mathrm{mg} / \mathrm{l}$ (DW26). According to BIS (1991) guidelines for acceptable limit of total alkalinity in drinking water is $200 \mathrm{mg} / \mathrm{l}$. The study reported that total alkalinity of majority of the water samples were above the acceptable limit prescribed by BIS for drinking water (1991) during the study period. The mean value of bicarbonate ion in the water samples was found as $167.31 \mathrm{mg} / \mathrm{l}, 143.79 \mathrm{mg} / \mathrm{l}$ and $201.88 \mathrm{mg} / \mathrm{l}$ during pre-monsoon, monsoon and post-monsoon respectively. Bicarbonate is the major anion in groundwater is coming from $\mathrm{CO}_{2}$ released by organic decomposition in the soil. The bicarbonate concentration is significantly higher in groundwater when compared to that of surface water.Hardness is due to the presence of the salts of calcium and magnesium compounds in the form of bicarbonates, sulphates and chlorides (Ramakrishnan, 1998). The hardness values recorded for water samples collected from the study area varied from $73 \mathrm{mg} / \mathrm{l}$ to $345 \mathrm{mg} / \mathrm{l}$ during pre monsoon, from $70 \mathrm{mg} / \mathrm{l}$ to $335 \mathrm{mg} / \mathrm{l}$ during monsoon and from $90 \mathrm{mg} / \mathrm{l}$ to 370 $\mathrm{mg} / \mathrm{l}$ during post monsoon seasons. Water is commonly classified based on the degree of hardness by Sawyer et al. (2003) as soft (0-75 $\mathrm{mg} / \mathrm{l})$; moderately hard $(75-150 \mathrm{mg} / \mathrm{l})$; hard (150$300 \mathrm{mg} / \mathrm{l}$ ) and very hard (above $300 \mathrm{mg} / \mathrm{l}$ ). In the present study, most of the water samples belong to moderately hard to very hard category except DW25 (pre-monsoon) and BW2 (monsoon). Hard water prevents foam formation when soap was used in bathing and laundry and form scales in utensils. 
Table 1 Analytical data of groundwater samples during pre-monsoon, monsoon and post-monsoon seasons

\begin{tabular}{|c|c|c|c|c|c|c|c|c|c|c|c|c|}
\hline \multirow[b]{2}{*}{ Parameters } & \multicolumn{4}{|c|}{ PRE-MONSOON } & \multicolumn{4}{|c|}{ MONSOON } & \multicolumn{4}{|c|}{ POST-MONSOON } \\
\hline & Average & SD & Min. & Max. & Average & SD & Min. & Max. & Average & SD & Min. & Max. \\
\hline $\mathrm{T}\left({ }^{\circ} \mathrm{C}\right)$ & 29.61 & 0.58 & 28.35 & 31.15 & 28.90 & 0.69 & 27.50 & 30.50 & 28.42 & 0.84 & 26.75 & 30.50 \\
\hline $\mathrm{pH}$ & 6.36 & 0.37 & 5.42 & 7.16 & 7.03 & 0.48 & 5.75 & 8.26 & 6.71 & 0.34 & 5.58 & 7.34 \\
\hline $\mathrm{EC}(\mu \mathrm{S} / \mathrm{cm})$ & 499.66 & 187.70 & 144.50 & 1015.50 & 549.37 & 270.26 & 165.15 & 1578.00 & 477.44 & 204.00 & 171.85 & 1228.50 \\
\hline $\mathrm{TS}(\mathrm{mg} / \mathrm{L})$ & 543.45 & 221.40 & 246.00 & 1090.00 & 460.49 & 181.55 & 112.00 & 1163.00 & 329.10 & 143.12 & 112.50 & 861.00 \\
\hline TDS (mg/l) & 309.60 & 116.27 & 91.00 & 657.00 & 285.88 & 138.41 & 88.50 & 815.00 & 243.85 & 102.65 & 75.00 & 609.00 \\
\hline TSS (mg/l) & 233.86 & 132.82 & 22.50 & 636.00 & 174.61 & 90.99 & 16.50 & 348.00 & 85.25 & 51.26 & 23.50 & 252.00 \\
\hline $\begin{array}{l}\mathrm{TA} \text { as } \mathrm{CaCO}_{3} \\
(\mathrm{mg} / \mathrm{l})\end{array}$ & 135.95 & 49.04 & 40.00 & 240.00 & 119.05 & 55.43 & 40.00 & 250.00 & 165.48 & 64.97 & 70.00 & 330.00 \\
\hline $\mathrm{HCO}_{3}{ }^{-}(\mathrm{mg} / \mathrm{l})$ & 167.31 & 57.93 & 48.80 & 292.80 & 143.79 & 65.31 & 48.80 & 305.00 & 201.88 & 79.26 & 85.40 & 402.60 \\
\hline $\begin{array}{l}\mathrm{TH} \text { as } \mathrm{CaCO}_{3} \\
(\mathrm{mg} / \mathrm{l})\end{array}$ & 177.07 & 58.31 & 73.00 & 345.00 & 140.71 & 52.57 & 70.00 & 335.00 & 211.19 & 63.71 & 90.00 & 370.00 \\
\hline $\mathrm{Ca}^{2+}(\mathrm{mg} / \mathrm{l})$ & 43.71 & 14.09 & 17.64 & 76.96 & 43.13 & 17.35 & 12.03 & 106.22 & 45.47 & 17.48 & 20.04 & 108.22 \\
\hline $\mathrm{Mg}^{2+}(\mathrm{mg} / \mathrm{l})$ & 18.80 & 7.90 & 8.53 & 52.39 & 8.12 & 3.99 & 2.44 & 19.50 & 23.70 & 8.62 & 6.09 & 51.17 \\
\hline $\mathrm{Na}^{+}(\mathrm{mg} / \mathrm{l})$ & 54.43 & 30.01 & 8.50 & 131.95 & 64.12 & 42.73 & 9.70 & 182.50 & 51.46 & 32.39 & 5.35 & 138.70 \\
\hline $\mathrm{K}^{+}(\mathrm{mg} / \mathrm{l})$ & 13.77 & 9.18 & 1.75 & 39.35 & 16.29 & 12.89 & 1.95 & 63.40 & 14.18 & 9.62 & 2.10 & 40.00 \\
\hline $\mathrm{NH}_{3}(\mathrm{mg} / \mathrm{l})$ & 0.07 & 0.09 & 0.02 & 0.61 & 0.10 & 0.17 & 0.01 & 0.73 & 0.09 & 0.11 & 0.01 & 0.50 \\
\hline $\mathrm{NO}_{2}^{-}(\mathrm{mg} / \mathrm{l})$ & 0.86 & 0.57 & 0.04 & 2.40 & 0.70 & 0.48 & 0.10 & 1.97 & 0.98 & 0.62 & 0.06 & 2.54 \\
\hline $\mathrm{NO}_{3}^{-}(\mathrm{mg} / \mathrm{l})$ & 1.96 & 1.12 & 0.27 & 4.14 & 3.56 & 0.82 & 1.79 & 5.10 & 3.95 & 0.81 & 2.33 & 6.12 \\
\hline $\mathrm{SO}_{4}^{2-}(\mathrm{mg} / \mathrm{l})$ & 26.93 & 17.04 & 3.07 & 72.44 & 33.35 & 21.59 & 6.50 & 134.57 & 28.78 & 21.68 & 3.44 & 86.82 \\
\hline $\mathrm{PO}_{4}^{3-}(\mathrm{mg} / \mathrm{l})$ & 0.71 & 0.87 & 0.00 & 4.71 & 0.59 & 0.46 & 0.00 & 1.71 & 0.81 & 0.68 & 0.01 & 2.24 \\
\hline $\mathrm{Cl}^{-}(\mathrm{mg} / \mathrm{l})$ & 59.84 & 26.77 & 17.04 & 137.03 & 66.49 & 37.98 & 17.75 & 202.35 & 58.63 & 26.52 & 21.30 & 145.55 \\
\hline Salinity $(\mathrm{mg} / \mathrm{l})$ & 109.81 & 49.12 & 31.27 & 251.45 & 121.91 & 69.55 & 32.57 & 371.31 & 107.59 & 48.66 & 39.09 & 267.08 \\
\hline Turbidity(NTU) & 0.64 & 1.10 & 0.10 & 6.35 & 0.63 & 0.98 & 0.10 & 5.70 & 1.14 & 0.78 & 0.55 & 4.65 \\
\hline
\end{tabular}

T Temperature, EC Electrical Conductivity, TS Total Solids, TDS Total Dissolved Solids, TSS Total

Suspended Solids, TA Total Alkalinity, TH Total Hardness, NTU Nephelometric Turbidity Unit, SD Standard Deviation

The scaling is caused by the deposition of $\mathrm{CaCO}_{3}$ and $\mathrm{Mg}(\mathrm{OH})_{2}$ (Abbasi, 1998). The present study showed that when people consuming this hardwater it may chance to occur cardiovascular diseases. The concentration of calcium in groundwater samples ranged between $17.64 \mathrm{mg} / \mathrm{l}(\mathrm{DW} 25)$ and $76.96 \mathrm{mg} / \mathrm{l}$ (DW26) during pre-monsoon season. During monsoon season, calcium content ranged from 20.04 to $106.22 \mathrm{mg} / \mathrm{l}$ whereas in post-monsoon season it ranged from 20.04 to $108.22 \mathrm{mg} / \mathrm{l}$. The concentration of magnesium ranged from 8.53 to $52.39 \mathrm{mg} / \mathrm{l}$ and 6.09 to $51.17 \mathrm{mg} / \mathrm{l}$ in pre-monsoon and post-monsoon seasons respectively. During the monsoon season the magnesium content in water samples were very low $(2.44-19.50 \mathrm{mg} / \mathrm{l})$.The average concentration of sodium in groundwater samples were recorded as $54.43 \mathrm{mg} / \mathrm{l}$ (pre- monsoon), $64.12 \mathrm{mg} / \mathrm{l}$ (monsoon) and $51.46 \mathrm{mg} / \mathrm{l}$ (post-monsoon). Most of the samples in the study area showed sodium content within the standard permissible limit. But water samples in some stations at DW7, DW15, DW18, DW19, DW 20, DW21, DW22, DW28, DW29 and BW11 showed high content of sodium during the study period. This may be due to the ingress of saline water from the study area to the groundwater sources. The only common mechanism for removal of sodium ion from natural waters is through ion exchange. The removal of sodium ion from sea water which is infiltered into fresh water aquifers has been attributed to ion exchange (Ramakrishnan, 1998). The mean concentration of potassium in water samples were observed as $13.77 \mathrm{mg} / \mathrm{l}, 16.29$ $\mathrm{mg} / \mathrm{l}$ and $14.18 \mathrm{mg} / \mathrm{l}$ in pre-monsoon, monsoon and 
post-monsoon seasons respectively. Most potable groundwater contains less potassium and commonly ranges between 1 and $5 \mathrm{ppm}$ (Ramakrishnan, 1998). Majority of the groundwater samples adjacent the sewage farm, Parvathy Puthen Ar canal and coastal area showed potassium values above the standard permissible limit of drinking water (BIS 1991).Nitrogen occurs in groundwater as dissolved organic nitrogen, ammonia, nitrite and nitrate. The major sources of nitrogen in groundwater are due to anthropogenic activities such as domestic sewage, waste water irrigation, fertilizers, organic waste disposal, and seepage from septic tanks. Shallow wells are more susceptible to nitrate contamination than bedrock wells (Jack and Sharma, 1983 and Ramsden, 1996). Under aerobic conditions, the natural concentration of nitrate in groundwater is few milligrams per litre and it depends on soil type and geological situation. As a result of human activities its concentration gradually increases (WHO, 2011). The concentration of ammonia in groundwater samples varied from 0.02 to $0.61 \mathrm{mg} / \mathrm{l}$ (pre-monsoon), 0.01 to $0.73 \mathrm{mg} / \mathrm{l}$ (monsoon) and 0.01 to $0.50 \mathrm{mg} / \mathrm{l}$ (postmonsoon). Natural levels in groundwaters are usually below $0.2 \mathrm{mg}$ of ammonia per litre (WHO, 2003). The minimum and maximum concentration of nitrites in water samples were recorded as 0.04 $2.40 \mathrm{mg} / \mathrm{l}, 0.10-1.97 \mathrm{mg} / \mathrm{l}, 0.06-2.54 \mathrm{mg} / \mathrm{l}$ during pre-monsoon, monsoon and post-monsoon seasons respectively. Nitrite levels in drinking-water are usually below $0.1 \mathrm{mg} / \mathrm{l}$ (WHO, 2011). The high concentration of nitrites in groundwater samples is due to the reduction mechanism of nitrate by microbial action in the study area. In normal groundwater, nitrate concentration is below $2 \mathrm{mg} / \mathrm{l}$ and its concentration gradually increases due to anthropogenic activities (Schivanna, 2008). During pre-monsoon season, nitrate content in groundwater samples varied from $0.27 \mathrm{mg} / \mathrm{l}$ to $4.14 \mathrm{mg} / \mathrm{l}$ whereas in monsoon season, it varied from 1.79 $\mathrm{mg} / \mathrm{l}$ to $5.10 \mathrm{mg} / \mathrm{l}$. The highest and lowest value was recorded as $6.12 \mathrm{mg} / \mathrm{l}$ and $2.33 \mathrm{mg} / \mathrm{l}$ during the post-monsoon season. The present study revealed that majority of the water samples collected from the study area showed the nitrate concentration above $2 \mathrm{mg} / \mathrm{l}$ for three seasons, but were within the permissible limit $(45 \mathrm{mg} / \mathrm{l})$ prescribed by WHO. This may be due to the leaching of waste water from sewage farm, septic tanks, Parvathy Puthen Ar canal and latrine pits to the groundwater sources. The sources of phosphates are sewage, fertilisers and household detergents. Compared to nitrates the phosphates are less soluble and moves slowly through the soil (Ramsden, 1996). The mobility of phosphates depends on the soil texture. The average concentration of phosphates in water samples estimated during pre-monsoon, monsoon and postmonsoon seasons were $0.71 \mathrm{mg} / 1,0.59 \mathrm{mg} / \mathrm{l}$ and $0.81 \mathrm{mg} / \mathrm{l}$ respectively. Majority of the groundwater samples showed phosphate values above the permissible limit $(0.3 \mathrm{mg} / \mathrm{l})$ prescribed by BIS (1991). The results of present study is in agreement with the study conducted by Ho and Notodarmojo (1995), who reported that phosphorus movement through sandy soil is higher than that of loamy soils. The present study showed that the sulphate content in all the water samples collected during the different seasons were within the standard desirable limit WHO (1994). The average concentration of chlorides in water samples were recorded as 59.84 $\mathrm{mg} / \mathrm{l}, 66.49 \mathrm{mg} / \mathrm{l}, 58.63 \mathrm{mg} / \mathrm{l}$ during pre-monsoon, monsoon and post-monsoon seasons respectively. In the present study, the chloride concentrations detected in the groundwater samples were within the desirable limits of WHO standards (1994) of drinking water quality. The water samples from DW7, DW15, DW18, DW19, DW20, DW21, DW22, DW28, DW29 and BW11 showed comparatively high content of chlorides in the three seasons studied. Salinity is an indication of the concentration of dissolved salts in water. During pre-monsoon, monsoon and post-monsoon seasons, the average value of salinity recorded in groundwater samples in the study area were 109.81 $\mathrm{mg} / \mathrm{l}, 121.91 \mathrm{mg} / \mathrm{l}$ and $107.59 \mathrm{mg} / \mathrm{l}$ respectively. The abundance of major anions in groundwater samples are in the order: $\mathrm{HCO}_{3}>\mathrm{Cl}>\mathrm{SO}_{4}>$ $\mathrm{NO}_{3}>\mathrm{PO}_{4}$ during the different seasons of the study period. Among the major cations, calcium was dominant in pre-monsoon and post-monsoon seasons whereas in monsoon season sodium was the dominant in the ground water samples of the study area.

\section{Relation between Soil texture and Groundwater quality}

The quality of groundwater depends on the surrounding soil texture. Texture refers to the proportions of sand, silt and clay sized particles in 
soil. It is important in determining properties such as soil fertility, water and air movement and water storage in soils (Brevik, 2013). Texture affects movement of water through soil and also the movement of dissolved pollutants such as pesticides. The coarser the soil, the faster is the movement of percolating water and the less opportunity for adsorption or evaporation (Iqbal et al. 2012). The present study showed that all the samples analysed from the study area is sandy texture (Fig. 2) and this may cause the rapid percolation of wastewater from sewage farm, latrine pits, Parvathy Puthen Ar canal to the shallow aquifers in the study area. It may result in the enrichment of ground water with phosphates, nitrates and other dissolved solids. Water percolation rates in sandy soils are much faster than in clayey soils (CESS, 2012). The study by Jalali (2007) showed that areas with sandy soils and shallow groundwater may have a chance of groundwater pollution.

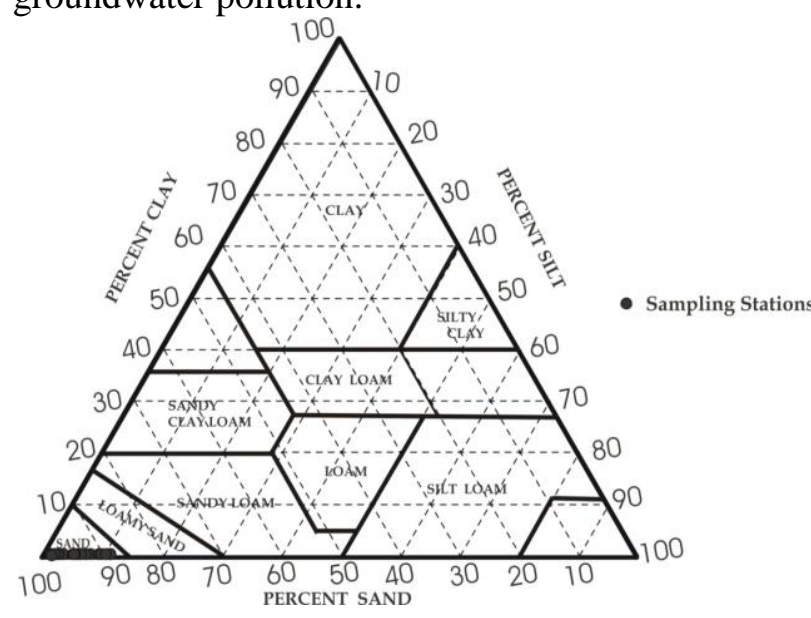

Fig. 2 Soil Textural Triangle diagram

\section{Gibbs Diagram}

It is used to understand the relation between water composition and aquifer (Gibbs, 1970). In this diagram, precipitation dominance, evaporation dominance and rock-water interaction dominance field are shown. The results showed that most of the groundwater samples fall under the rock-water dominance during pre-monsoon, monsoon and post-monsoon seasons (Fig.3).

\section{Chloro-alkaline Indices (CAI)}

Chloro-alkaline Indices are used to study the ion exchange between the groundwater and its aquifer environment (Schoeller, 1977). The positive value of CAI1 and CAI2 indicates that the sodium and potassium from water are exchanged with magnesium and calcium in rock favouring base exchange reactions (chloro-alkaline equilibrium). The negative value of CAI1 and CAI2 explains the magnesium and calcium from water are exchanged with sodium and potassium in rock favouring cation-anion exchange reactions (chloro-alkaline disequilibrium). Based on this, all the samples except DW3 and DW25 showed negative chloroalkaline indices during pre-monsoon season. In monsoon season, majority of samples comes in negative CAI except DW23 and DW25. During post-monsoon season about $28.5 \%$ and $71.5 \%$ water samples belong to positive and negative CAI respectively. The results revealed that there are cation-anion exchange reactions in the groundwater samples of the study area.

\section{Hydrochemical Facies}

Piper (1944) Trilinear diagram is used to understand the water type of the study area. This diagram consists of two lower triangular fields and a central diamond shaped field. The percentage reacting values of the cations and anions are plotted as a single point at the lower left and right angles respectively. These are projected upwards parallel to the sides of the triangles to give point which indicates the water quality types (Raghunath, 1987). The diagram reveals similarities and differences among groundwater samples because those with similar qualities will tend to plot together as groups (Todd, 2001). The Piper plot can be classified into six categories viz, I $\left(\mathrm{Ca}-\mathrm{HCO}_{3}\right.$ type); II ( $\mathrm{Na}-\mathrm{Cl}$ type); III (Mixed $\mathrm{Ca}-\mathrm{Na}-\mathrm{HCO}_{3}$ type); IV (Mixed $\mathrm{Ca}-\mathrm{Mg}-\mathrm{Cl}$ type); $\mathrm{V}$ (Ca-Cl type) and VI ( $\mathrm{Na}-\mathrm{HCO}_{3}$ type). The Fig.4 showed that during pre-monsoon and post-monsoon season majority of the groundwater samples were Ca$\mathrm{HCO}_{3}$ type whereas in monsoon season $\mathrm{Na}-\mathrm{Cl}$ type were dominant. The $\mathrm{Na}-\mathrm{Cl}$ type water indicates that the groundwater samples in the study area is mixed with sea water due to the tidal effect. The remaining samples fall in mixed water type during the study periods.

\section{Interrelationship between Physico-chemical Parameters}

Pearson correlation coefficient is used to study the nature and strength of relationship between two variables. 
Varghese and Jaya
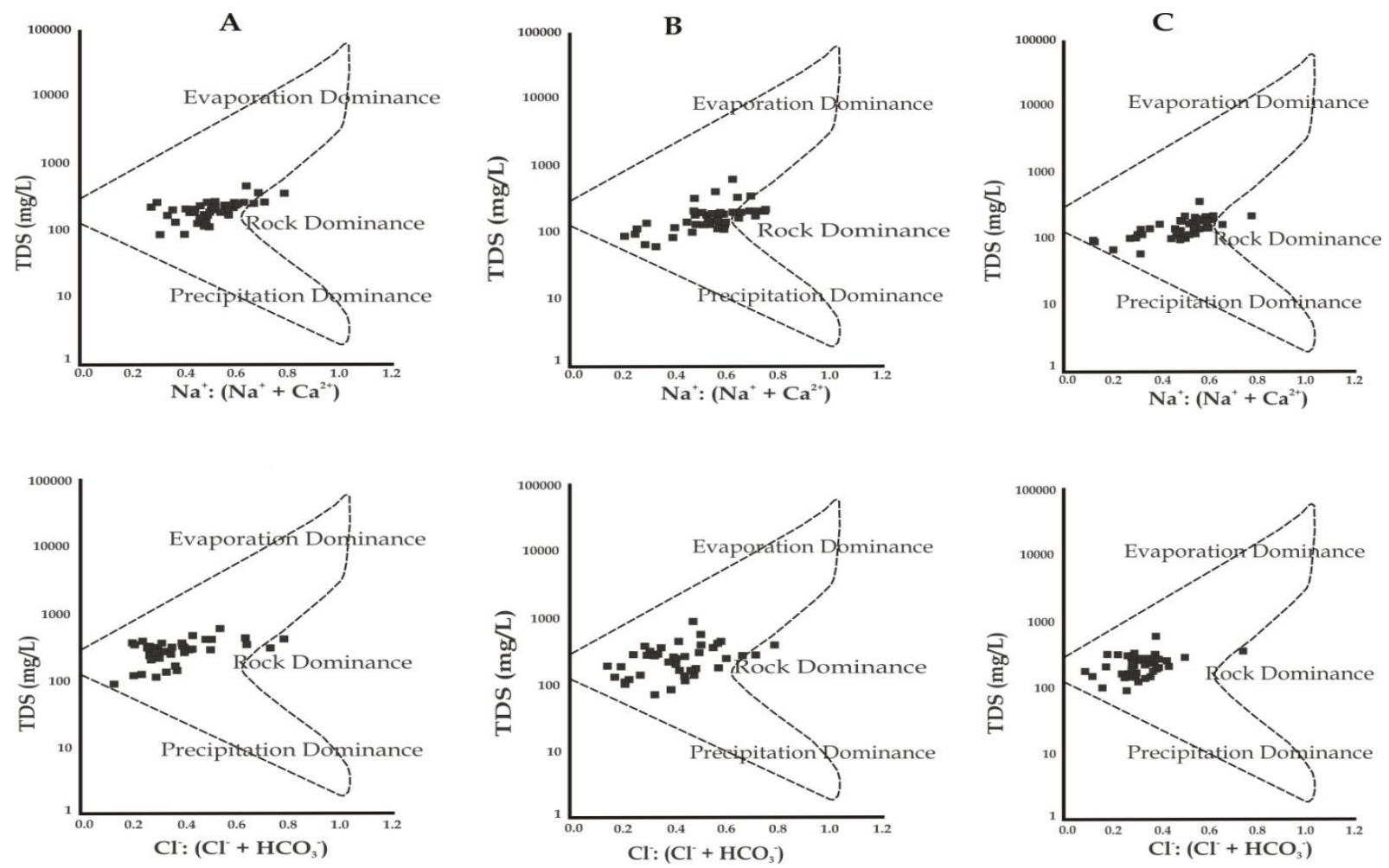

Fig. 3 Controlling mechanisms for groundwater quality during (A) Pre-monsoon (B) Monsoon and (C) Post-monsoon seasons
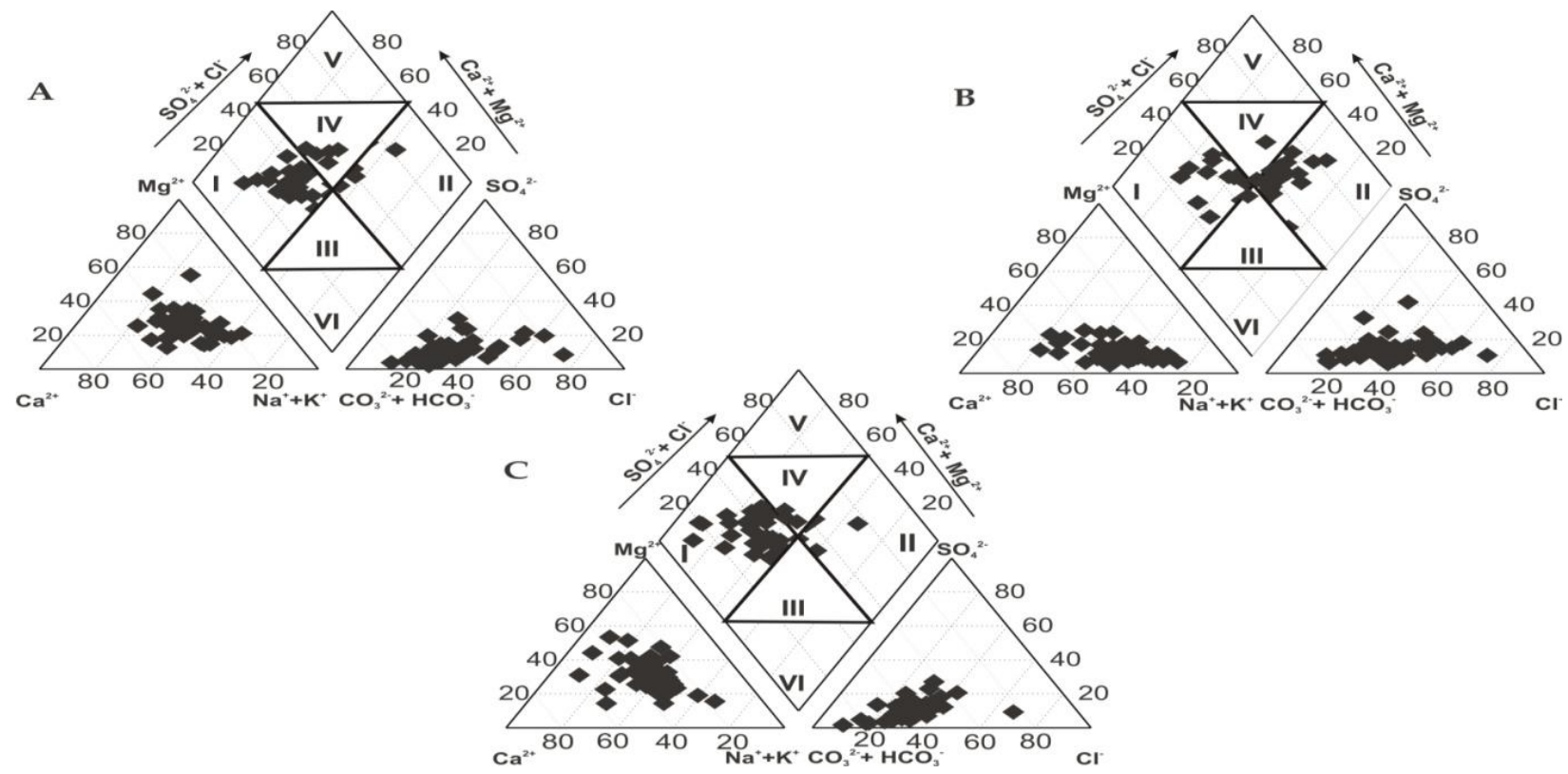

Fig. 4 Piper diagram of groundwater during (A) Pre-monsoon (B) Monsoon and (C) Post-monsoon seasons

142

Environment Conservation Journal 
Based on groundwater chemistry, three sets of strong relationships exist between major cations and anions (Douglas and Leo, 1977) are (1) The highly competitive relationship between ions having same charge but a different valence number e.g. $\mathrm{Ca}^{2+}$ and $\mathrm{Na}^{+}$(2) The affinity between ions having different charges but the same valence number e.g. $\mathrm{Na}^{+}$and $\mathrm{Cl}^{-}$(3) The non-competitive relationship between ions having the same charge and same valence number e.g. $\mathrm{Ca}^{2+}$ and $\mathrm{Mg}^{2+}$ (Kumar and Divya, 2012; Manjusree et al. 2009).

The highly competitive relationship: $\mathrm{Ca}^{2+}$ with $\mathrm{Na}^{+}$ $\left(0.563^{* *}\right)$ and $\mathrm{Ca}^{2+}$ with $\mathrm{K}^{+}\left(0.561^{* *}\right)$ have significant correlation. $\mathrm{SO}_{4}{ }^{2-}$ with $\mathrm{Cl}^{-}\left(0.461^{* *}\right)$ has low positive correlation (Table 2). The affinity ions relationship: $\mathrm{Na}^{+}$with $\mathrm{Cl}^{-}\left(0.868^{* *}\right)$ has strong positive correlation. $\mathrm{Ca}^{2+}$ with $\mathrm{SO}_{4}{ }^{2-}(0.549 * *)$ has low positive correlation.The non-competitive relationship: $\mathrm{Na}^{+}$with $\mathrm{K}^{+}(0.822 * *)$ has significant correlation. $\mathrm{Ca}^{2+}$ with $\mathrm{Mg}^{2+}(0.238 * *)$ and $\mathrm{HCO}_{3}$ with $\mathrm{Cl}^{-}(0.061)$ has very low positive correlation.

The present study found that electrical Conductivity of groundwater samples showed strong positive correlation with TS $\left(0.796^{* *}\right)$, TDS $\left(0.971^{* *}\right), \mathrm{Ca}^{2+}$ $(0.740 * *), \quad \mathrm{Na}^{+}\left(0.921^{* *}\right), \mathrm{K}^{+}(0.817 * *), \quad \mathrm{Cl}^{-}$ $(0.837 * *)$ (Table 2) From the analysis, it can be concluded that high concentration of $\mathrm{EC}$ in groundwater is due to the influence of dissolved ions from the waste water. A significant positive correlation $\left(0.868^{* *}\right)$ was found between sodium ion and chloride ion in the groundwater samples. This may be due to the ingress of salt water from the Parvathy Puthen Ar canal or from the sea to the groundwater sources in the study area.

\section{Groundwater quality for Irrigation}

The suitability of groundwater for irrigation purpose mainly depends on the type and quantity of dissolved solids. High concentration of salts directly or indirectly affects both plants and soils. Salts may harm plant growth physically by limiting the uptake of water through modification of osmotic pressure or chemically by metabolic reactions such as those caused by toxic constituents. Effects of salts on soils, causing changes in soil structure, permeability and aeration, indirectly affect plant growth (Todd, 2001).The results of the groundwater classification for irrigation purpose based on different irrigational quality parameters are presented in Table 3.

\section{Sodium Adsorption Ratio (SAR)}

SAR is an important parameter for determining the suitability of groundwater irrigation. Based on SAR value, the quality of water can be categorised as Excellent $(<10)$; Good (10-18); Doubtful (18-26) and Unsuitable (>26) (Raghunath, 1987). In this study, the SAR values obtained for all the groundwater samples analysed in the three seasons comes under excellent category.The US Salinity laboratory (USSL) diagram (Richards, 1954) was used for rating the irrigation waters, where SAR is plotted against electrical conductivity. The sixteen classes in the diagram indicate that the salinity hazard as low (C1), medium (C2), high (C3) and very high $(\mathrm{C} 4)$ and similarly sodium hazard as low (S1), medium (S2), high (S3) and very high (S4). Groundwater classification based on USSL diagram is shown in Fig 5. According to USSL classification, about $78.5 \%$ samples belong to $\mathrm{C} 2 \mathrm{~S} 1$ category, and $9.6 \%$ and $11.9 \%$ samples falling $\mathrm{C} 1 \mathrm{~S} 1$ and $\mathrm{C} 3 \mathrm{~S} 1$ class respectively during the premonsoon season. In monsoon season, about $71.4 \%$ samples come under $\mathrm{C} 2 \mathrm{~S} 1$ category and the remaining samples are under $\mathrm{C} 1 \mathrm{~S} 1$ and $\mathrm{C} 3 \mathrm{~S} 1$ class whereas in post-monsoon season about $85.7 \%$ water samples falls in C2S1 category.

\section{Percent Sodium (\%Na)}

Sodium concentration is important in classifying irrigation water because sodium reacts with soil to reduce its permeability. Soils containing large proportion of sodium with carbonate as the predominant anion are called alkali soils and those with chloride or sulphate as the predominant anion are known as saline soils (Todd, 2001). According to $\% \mathrm{Na}$ value, water quality for irrigation purpose can be marked as <20 (Excellent); 20-40 (Good); 40-60 (Permissible); 60-80 (Doubtful) and >80 (Unsuitable) (Raghunath, 1987). Based on this, majority of the samples come under excellent to permissible category in three seasons. Wilcox (1948) classified the groundwater for irrigation purpose by plotting percent sodium against electrical conductivity. Based on Wilcox's diagram (Fig.6) majority of the groundwater samples in the study area belongs to Excellent-good to goodpermissible during the different seasons studied. But the water samples DW15, DW18, DW28, DW29 and BW11 come under permissible to doubtful category in monsoon and post monsoon seasons. 


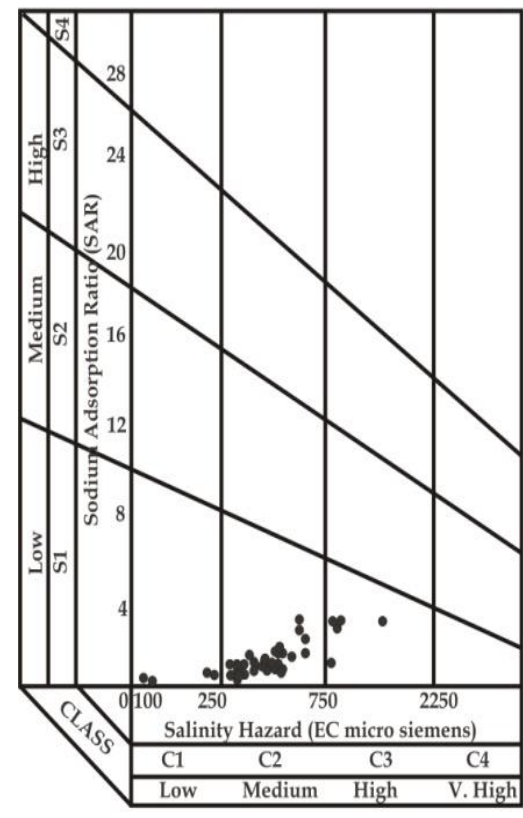

A

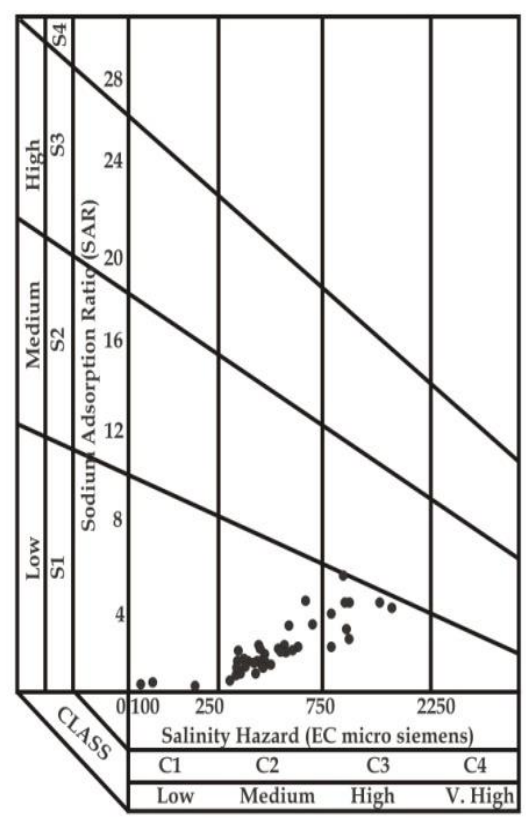

B

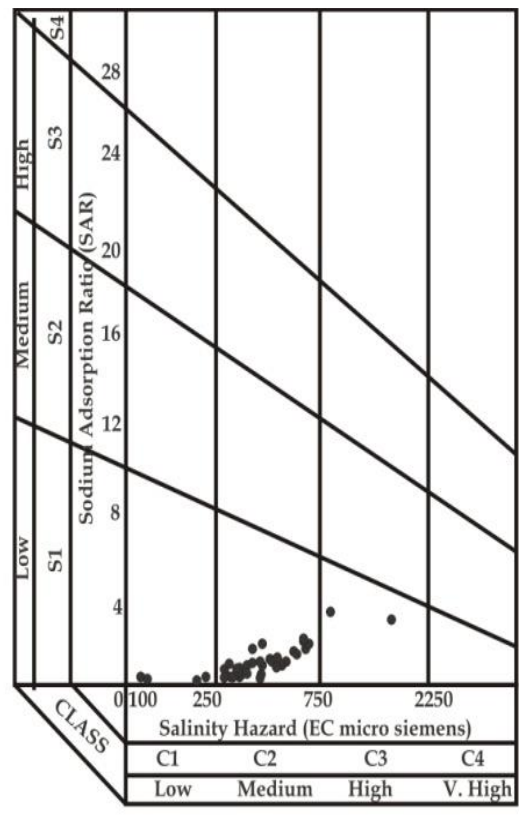

C

Fig. 5 Rating of groundwater samples in relation to salinity and sodium hazard during (A) Premonsoon (B) Monsoon and (C) Post-monsoon seasons

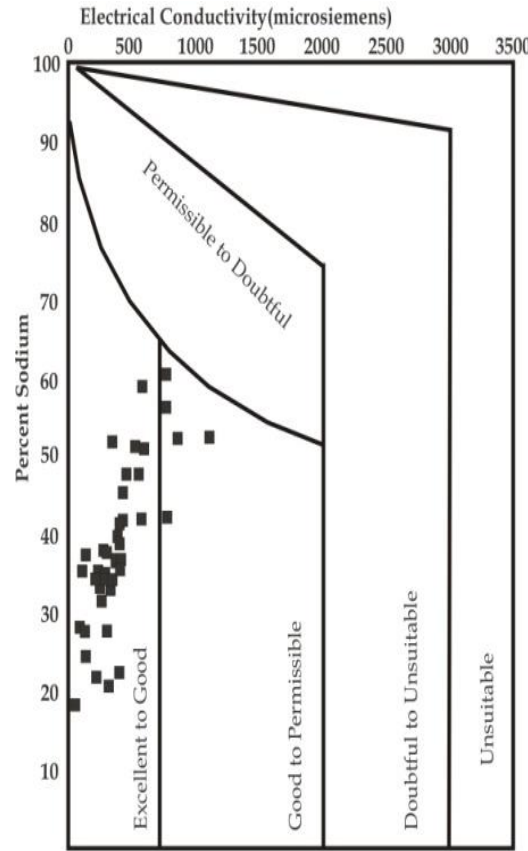

A

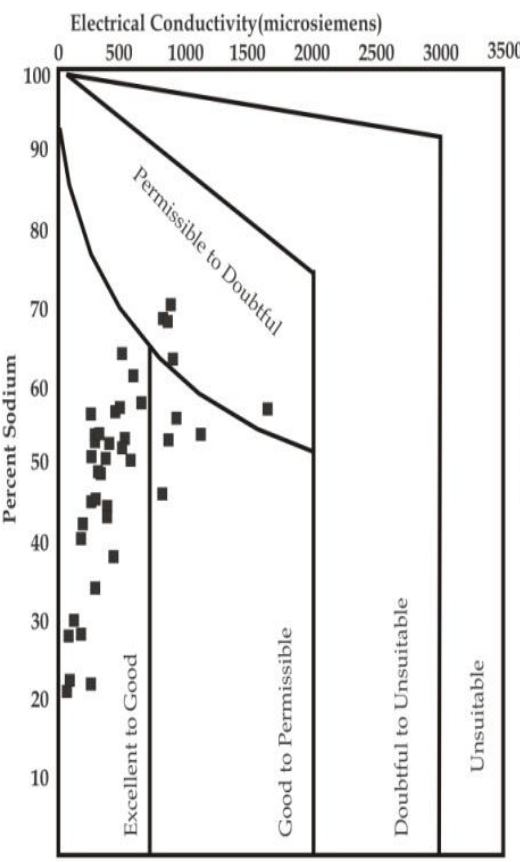

B
Electrical Conductivity(microsiemens)

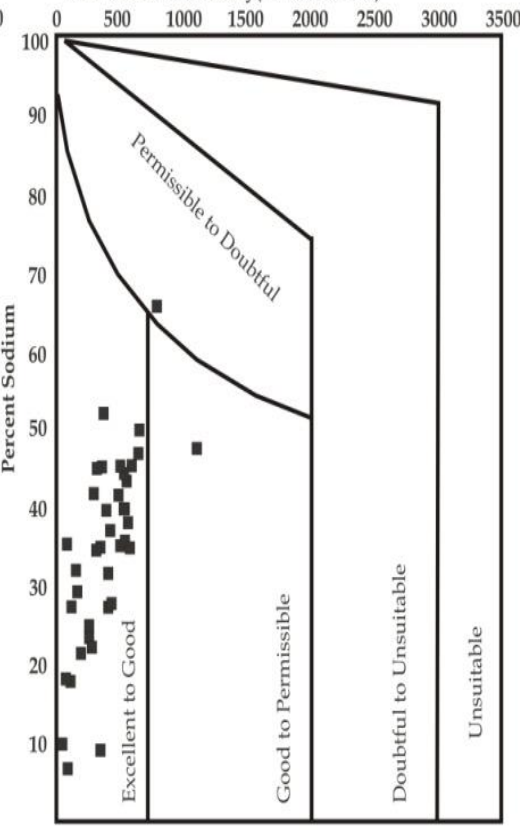

C

Fig. 6 Wilcox diagram of groundwater samples during (A) Pre-monsoon (B) Monsoon and (C) Postmonsoon seasons. 
Table 2 Interrelationship between physico-chemical parameters of groundwater samples during Pre-monsoon, Monsoon and Post-monsoon seasons

\begin{tabular}{|c|c|c|c|c|c|c|c|c|c|c|c|c|c|c|c|c|c|c|c|c|c|}
\hline & 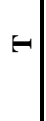 & 焉 & $\underbrace{0}_{\text {工工工 }}$ & 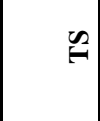 & $\mathscr{E}$ & S & 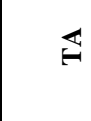 & $\overbrace{}^{\infty}$ & 档 & שٓ & $\sum^{+\infty}$ & ${ }^{+}$ & \pm & $\overline{\mathbf{Z}}$ & 's' & '̊n & $\tilde{i}_{+}^{+}$ & $\overbrace{0}^{+}$ & $\dot{\tau}$ & 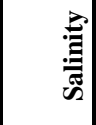 & 䏤 \\
\hline $\mathbf{T}$ & 1 & $-.407^{* *}$ & -.155 & .146 & -.040 & $.303^{* *}$ & $-.432^{* *}$ & $-.435^{* *}$ & $-.298^{* *}$ & $-.315^{* *}$ & -.111 & -.091 & -.103 & -.058 & -.001 & $-.328^{* *}$ & -1.137 & -.104 & -.021 & -.021 & -.168 \\
\hline pH & & 1 & .083 & $-.236^{* *}$ & -.013 & $-.405^{* * *}$ & $.393^{* *}$ & $.371^{\text {** }}$ & .050 & $.271^{* *}$ & $-.260^{* * *}$ & .058 & .052 & -.028 & $-.193^{*}$ & $.216^{*}$ & .104 & .070 & -.034 & -.035 & -.141 \\
\hline EC & & & 1 & $.796^{* *}$ & $.971^{* *}$ & $.380^{\text {** }}$ & $.247^{* *}$ & $.247^{* *}$ & $.587^{* *}$ & $.740^{* *}$ & $.184^{*}$ & $.921^{* *}$ & $.817^{* *}$ & $.352^{* *}$ & $.297^{* *}$ & .141 & $.606^{* *}$ & .069 & $.864^{* *}$ & $.864^{\text {** }}$ & $-.208^{*}$ \\
\hline TS & & & & 1 & $.870^{* *}$ & $.850^{* *}$ & -.071 & -.064 & $.356^{* *}$ & $.483^{* *}$ & .151 & $.722^{* *}$ & $.681^{* *}$ & $.277^{* *}$ & $.299^{* *}$ & \begin{tabular}{|l|}
-.061 \\
\end{tabular} & $.486^{* *}$ & .029 & $.679^{* *}$ & $.679^{* *}$ & $-.253^{* *}$ \\
\hline TDS & & & & & 1 & $.479^{* *}$ & $.189^{*}$ & $.194^{*}$ & $.557^{* *}$ & $.697^{* *}$ & $.208^{*}$ & $.892^{* *}$ & $.792^{* * *}$ & $.301^{* *}$ & $.317^{* *}$ & .019 & $.572^{* *}$ & .081 & $.837^{* *}$ & $.837^{* *}$ & $-.262^{* *}$ \\
\hline TSS & & & & & & 1 & $-.328^{* *}$ & $-.321^{* *}$ & .039 & .114 & .046 & $.333^{* *}$ & $.366^{* * *}$ & .171 & $.194^{*}$ & -.129 & $.253^{* * *}$ & -.035 & $.315^{* *}$ & $.315^{* *}$ & -.170 \\
\hline TA & & & & & & & 1 & $.996^{* *}$ & $.497^{* *}$ & $.549^{* *}$ & $.284^{* *}$ & $.202^{*}$ & .156 & .138 & .085 & -.013 & .125 & .065 & .067 & .068 & $.197^{*}$ \\
\hline $\mathrm{HCO}_{3}^{-}$ & & & & & & & & 1 & $.504^{* *}$ & $.547^{* *}$ & $.291^{* *}$ & $.194^{*}$ & .143 & .142 & .095 & -.025 & .121 & .069 & .061 & .062 & $.197^{*}$ \\
\hline TH & & & & & & & & & 1 & $.770^{* *}$ & $.675^{* *}$ & $.433^{* *}$ & $.439^{* * *}$ & $.203^{*}$ & $.302^{* *}$ & .085 & $.418^{* *}$ & .091 & $.424^{* * *}$ & $.425^{* *}$ & -.060 \\
\hline $\mathrm{Ca}^{2+}$ & & & & & & & & & & 1 & $.238^{* * *}$ & $.563^{* *}$ & $.561^{* * *}$ & $.248^{* * *}$ & $.205^{*}$ & .012 & $.549^{* *}$ & .009 & $.508^{* *}$ & $.509^{* *}$ & -.099 \\
\hline $\mathrm{Mg}^{2+}$ & & & & & & & & & & & 1 & .148 & $.188^{*}$ & .005 & \begin{tabular}{|l|}
$.190^{*}$ \\
\end{tabular} & .080 & .147 & .067 & .157 & .157 & .008 \\
\hline $\mathrm{Na}^{+}$ & & & & & & & & & & & & 1 & $.822^{* *}$ & $.309^{* *}$ & $.306^{* *}$ & .144 & $.554^{* *}$ & .116 & $.868^{* *}$ & $.869^{* *}$ & $-.246^{* *}$ \\
\hline $\mathbf{K}^{+}$ & & & & & & & & & & & & & 1 & $.303^{* *}$ & $.341^{* *}$ & $.177^{*}$ & $.474^{* *}$ & .078 & $.694^{* *}$ & $.693^{* *}$ & $-.191^{*}$ \\
\hline $\mathrm{NH}_{3}$ & & & & & & & & & & & & & & 1 & \begin{tabular}{|l|}
$.183^{*}$ \\
\end{tabular} & .042 & .158 & -.089 & $.278^{* * *}$ & $.278^{* *}$ & -.031 \\
\hline $\mathrm{NO}_{2}^{-}$ & & & & & & & & & & & & & & & 1 & $.208^{*}$ & $.211^{*}$ & .118 & $.207^{*}$ & $.207^{*}$ & -.043 \\
\hline $\mathrm{NO}_{3}{ }^{-}$ & & & & & & & & & & & & & & & & 1 & .161 & $.180^{*}$ & .110 & .110 & -.030 \\
\hline $\mathrm{SO}_{4}{ }^{2-}$ & & & & & & & & & & & & & & & & & 1 & .027 & $.461^{* *}$ & $.461^{* *}$ & $-.181^{*}$ \\
\hline $\mathrm{PO}_{4}{ }^{3-}$ & & & & & & & & & & & & & & & & & & 1 & .013 & \begin{tabular}{|l|}
.013 \\
\end{tabular} & -.032 \\
\hline $\mathrm{Cl}^{-}$ & & & & & & & & & & & & & & & & & & & 1 & $1.000^{* * *}$ & $-.208^{*}$ \\
\hline Salinity & & & & & & & & & & & & & & & & & & & & 1 & $-.208^{*}$ \\
\hline $\begin{array}{c}\text { Turbidit } \\
\mathbf{y}\end{array}$ & & & & & & & & & & & & & & & & & & & & & 1 \\
\hline
\end{tabular}

**. Correlation is significant at the 0.01 level (2-tailed), * Correlation is significant at the 0.05 level (2-tailed).

Residual Sodium Carbonate (RSC)

It is the bicarbonate content of water suggested by Eaton (1950). High concentration of bicarbonate ion in irrigation water leads to toxicity and affects the mineral nutrition of plants (Arabi et al. 2010). If RSC $>2.5 \mathrm{meq} / \mathrm{l}$, the water is considered as unsuitable for irrigation and if the value of RSC between 1.25 and $2.5 \mathrm{meq} / \mathrm{l}$, the water is marginally suitable, and the value of RSC $<1.25 \mathrm{meq} / 1$, it is safe for irrigation purposes. In the present study, about $81 \%, 97.6 \%$ and $92.8 \%$ groundwater samples belong to safe to marginally suitable class during the pre-monsoon, monsoon and post-monsoon seasons respectively.

\section{Magnesium Ratio (MR)}

It is defined as the excess amount of magnesium over calcium. Excess amount of magnesium affects the quality of soils and there by leads to poor yield of crops (Pandian and Sankar, 2007). If MR >50, the water is considered as harmful and unsuitable for irrigation while $\mathrm{MR}<50$ makes it suitable (Lloyd and Heathcoat, 1985). In this study, out of total 42 samples, about $81 \%$ and $69 \%$ samples belongs to suitable category during pre-monsoon and post-monsoon seasons respectively whereas in monsoon season all the groundwater samples $(100 \%)$ are suitable for irrigation purposes.Kelly's Ratio (KR) The level of sodium measured against calcium and magnesium is known as Kelly' ratio, based on which irrigation water can be rated (Kelley, 1946 and Paliwal, 1967). The Kelly's ratio $<1$ indicates the good quality of water for irrigation, whereas $>1$ considered as unsuitable for irrigation purpose (Karanth, 1987). The results in the present study shows that during pre-monsoon season about 
Varghese and Jaya

Table 3 Groundwater classification for irrigation purpose

\begin{tabular}{|c|c|c|c|c|c|c|c|c|}
\hline \multirow[b]{2}{*}{ Parameters } & \multirow[b]{2}{*}{ Range } & \multirow[b]{2}{*}{$\begin{array}{c}\text { Water } \\
\text { Category }\end{array}$} & \multicolumn{2}{|c|}{ PRE-MONSOON } & \multicolumn{2}{|c|}{ MONSOON } & \multicolumn{2}{|c|}{ POST-MONSOON } \\
\hline & & & $\begin{array}{c}\text { No. of } \\
\text { samples } \\
\end{array}$ & $\begin{array}{c}\% \text { of } \\
\text { samples }\end{array}$ & $\begin{array}{c}\text { No. of } \\
\text { samples }\end{array}$ & $\begin{array}{c}\% \text { of } \\
\text { samples } \\
\end{array}$ & $\begin{array}{c}\text { No. of } \\
\text { samples } \\
\end{array}$ & $\%$ of samples \\
\hline \multirow{5}{*}{$\% \mathrm{Na}$} & $<20$ & Excellent & 1 & 2.4 & Nil & Nil & 5 & 11.9 \\
\hline & $20-40$ & Good & 24 & 57.1 & 9 & 21.4 & 21 & 50.0 \\
\hline & $40-60$ & Permissible & 16 & 38.1 & 27 & 64.3 & 16 & 38.1 \\
\hline & $60-80$ & Doubtful & 1 & 2.4 & 6 & 14.3 & 1 & 2.4 \\
\hline & $>80$ & Unsuitable & Nil & Nil & Nil & Nil & Nil & Nil \\
\hline \multirow{3}{*}{ RSC } & $<1.25$ & safe & 21 & 50.0 & 26 & 61.9 & 25 & 59.5 \\
\hline & 1.25 & marginally & 13 & 31.0 & 15 & 35.7 & 14 & 33.3 \\
\hline & $>2.5$ & Unsuitable & 8 & 19.0 & 1 & 2.4 & 3 & 7.1 \\
\hline \multirow{2}{*}{ MR } & $<50$ & Suitable & 34 & 81.0 & 42 & 100.0 & 29 & 69.0 \\
\hline & $>50$ & Unsuitable & 8 & 19.0 & Nil & Nil & 13 & 31.0 \\
\hline \multirow{3}{*}{ PI } & $>75$ & Excellent & 7 & 16.7 & 25 & 59.5 & 4 & 9.5 \\
\hline & $25-75$ & Good & 35 & 83.3 & 17 & 40.5 & 38 & 90.5 \\
\hline & $<25$ & Unsuitable & Nil & Nil & Nil & Nil & Nil & Nil \\
\hline \multirow{2}{*}{$\mathrm{KR}$} & $<1$ & Suitable & 39 & 92.9 & 25 & 59.5 & 40 & 95.2 \\
\hline & $>1$ & Unsuitable & 3 & 7.1 & 17 & 40.5 & 2 & 4.8 \\
\hline \multirow{4}{*}{ SAR } & $<10$ & Excellent & 42 & 100 & 42 & 100.0 & 42 & 100.0 \\
\hline & $10-18$ & Good & Nil & Nil & Nil & Nil & Nil & Nil \\
\hline & $19-26$ & Doubtful & Nil & Nil & Nil & Nil & Nil & Nil \\
\hline & $>26$ & Unsuitable & Nil & Nil & Nil & Nil & Nil & Nil \\
\hline
\end{tabular}

\% Na Percent Sodium, RSC Residual Sodium Carbonate, MR Magnesium Ratio, PI Permeability Index, KR Kelly's Ratio, SAR Sodium Adsorption Ratio

92.9\% water samples reported $\mathrm{KR}<1$, indicating good quality of water for irrigation and the remaining samples $(7.1 \%)$ such as DW18, DW21 and BW11 showed KR $>1$. In monsoon season about $59.5 \%$ groundwater samples in the study area observed $\mathrm{KR}<1$ and rest of it is unfit for irrigation. All the water samples except from two stations (DW12 and BW11) are suitable for irrigation during post-monsoon season.

\section{Permeability Index (PI)}

It is another important determinant for measuring the suitability of groundwater for irrigation purpose. The permeability index was developed by Doneen (1964). Based on the permeability indices, water can be classified into Class I, Class II and Class III types. Class I and Class II types are suitable for irrigation with $75 \%$ of maximum permeability and Class III types of water with $25 \%$ of maximum permeability. The present study showed that all the samples analysed in the study area belong to Class I and Class II category in three seasons which is suitable for irrigation purpose. The soil permeability is affected by long term use of irrigation water and is influenced by sodium, calcium, magnesium and bicarbonate contents of the soil (Raju et al. 2009).

\section{Conclusion}

Therefore the study conclude that among the groundwater bodies evaluated for water quality, the dug wells adjacent to the sewage farm and Parvathy Puthen Ar canal showed more chemical contamination compared to that of bore wells in the study area. It is suggested to implement effective management measures like periodic cleaning of dug wells, disinfection of groundwater by using suitable disinfectants and dug well is constructed giving proper distance from septic tank must be implemented to protect the groundwater sources in the study area. 


\section{Acknowledgements}

The financial assistance for this study from Kerala State Council for Science and Technology is gratefully acknowledged. The authors are also thankful to Dr. Sabu Joseph (Reader, Dept. of Environmental Sciences, University of Kerala) and Dr. Jobin Thomas (Research Associate, Inter University Centre for Geo Information Science and Technology, University of Kerala) for giving valuable suggestions and help to carryout this work.

\section{References}

Abbasi, S. A. 1998. Water Quality Sampling and Analysis, Discovery publishing house, New Delhi, p.212.

Arabi, Abdullahi, S., Funtua, Isa, I., Alagbe, Ayodele, S., Zabsrki, Peter, and Muhammad, B.B. 2010. Investigation of groundwater quality for domestic and irrigation purposes around Gubrunde and Environs, northeastern Nigeria. Journal of American Science, 6(12):664-672.

APHA 1995. Standards methods for the examination of water and wastewater, 19th Edn. American Public Health Association, Washington Dc.

BIS 1991. Drinking water specifications, Bureau of Indian Standards, IS: 10500.

Brevik, E.C. 2013. An introduction to soil science basics. In Brevik EC and Burgess LC (Eds.), Soils and Human Health, CRC Press. New York, pp: 3-27.

CESS 2012. Soil Geochemical Atlas of Kannur district. Part of Plan Project-273. Assessment and monitoring of land quality for sustainable agriculture in Kannur district. A GIS based approach coupled with Technology implementation.

Chithra, V.S. 2010. Studies on the physico-chemical characteristics of sewage irrigated soils and their effects on plants. $\mathrm{PhD}$ Thesis, University of Kerala.

Doneen, L. D. 1964. Notes on water quality in Agriculture, Published as a water science and engineering paper, 4001, Department of water scince and engineering, University of California.

Douglas, E.B. and Leo, W.N. 1977. Hydrogeochemical relationships using partial correlation coefficient. Water Resource Bulletin, 13,843-846.

Eaton, F. M. 1950. Significance of carbonates in irrigation waters. Soil Science 39,123-133.

Gibbs, R. J. 1970.Mechanism controlling world water chemistry, Science, 170: 1088-1090.
Gwenzi, W., and Munondo, R. 2008. Long term impacts of pasture irrigation with treated sewage effluent on shallow groundwater quality. Water Science Technology 58(12), 2443-2452.

Ho, G. E., and Notodarmojo, S. 1995. Phosphorous movement through soils and groundwater: application of a time dependent model. Water Science and technology, 31(9), 83-90.

Iqbal, J., Gorai, A.K., Tirkey, P., and Pathak, G. 2012. Approaches to groundwater vulnerability to pollution: A literatutre review. Asian Journal of Water Environment and Pollution, 9, 105-115.

Jack, G., and Sharma, V. P. 1983. Nitrogen circulation and nitrate in groundwater in an agricultural catchment in Southern India. Environmental Geochemistry, 5(2), 61-64.

Jackson, M.C. 1967 .Soil and chemical analysis, Prentice Hall Inc. New Jersey

Jalali, M. 2007. Hydrochemical identification of groundwater resources and their changes under the impacts of human activity in the Chah Basin in Western Iran. Environmental Monitoring Assessment pp130: 347-364.

Karanth, K. R. 1987. Groundwater assessment, development and management, Tata Mc Graw Hill Publishing Company Limited, New Delhi.

Kelley, W. P. 1946. Alkali soil-Their formation properties and Reclamation. Reinold Publication, New York, pp.124-128.

KSUDP 2008. Kerala State Urban Development Project Design, Initial Environmental Examination, Thiruvananthapuram.

Kumar, A. 2002. Biomonitoring of Sewage Pollution, APH Publishing Corporation, New Delhi, p.402

Kumar, R.B.B. and Divya, M.P. 2012. Spatial Evaluation of Groundwater Quality in Kazakuttam Block, Thiruvananthapuram District, Kerala. Journal of Geological Society of India, 80:48-56.

Lloyd, J. W. and Heathcoat, J. A. 1985. Natural inorganic hydrochemistry in relation to groundwater: an introduction, Oxford University Press, NewYork, pp.296.

Mahmood, S. and Maqbool, A. 2006. Impacts of waste water irrigation on water quality and on the Health of local community in Faisalabad,Pakistan. Journal of Water Resources, 10(2): 19-22.

Manjusree, T. M. Joseph, S. and Thomas, J. 2009. Hydrogeochemistry and Groundwater Quality in the Coastal Sandy Clay aquifers of Alappuzha District, Kerala. Journal of Geological Society of India,74:459-468. 
Meena, M. K., Dutta, S. and Pradhan, R. 2010. Environmental impacts of waste water irrigation on groundwater quality- a case study of Ajmer city, Rajasthan (India). Electronic journal of Environmental, Agricultural and Food Technology, 9(4):760-766.

Omana, P. K. 2002. Geo environmental studies of sewage pollution around Muttathara sewage farm in Thiruvananthapuram city, CESS, Thiruvananthapuram.

Paliwal, K.V. 1967. Effect of Gypsum application on the quality of water. The Madras Agriculture Journal, 59: 646-647.

Pandian, K., and Sankar, K. 2007. Hydrochemistry and Groundwater Quality in the Vaippar River Basin, Tamil Nadu. Journal of Geological Society of India, 69:970-982.

Piper, A. M. 1944. A graphical procedure in the geochemical interpretation of water, Transactions American Geophysical Union, 25:914-928.

Quin, B. F. 1978. The effects of drainage from surface irrigation with treated sewage effluent on groundwater quality at Templeton. Journal of Hydrology, 17(2), 91102.

Raghunath, H. M. 1987. Groundwater, New Age International (P) Limited Publishers, New Delhi.

Raju, N. J., Kotaiah, B., and Reddy, T. V. K. 1991. Biogeochemical aspects in and around a sewage farm at Tirupati, Andhra Pradesh, India. Environmental Conservation, 18(3):267-269.

Raju, N. J., Ram, P., and Dey, S. 2009. Groundwater quality on the lower Varuna River Basin, Varanasi District, Uttar Pradesh. Journal of Geological Society of India, 73:178192.

Rajvaidhya, N., and Markandey, D. K. 2005. Environmental Analysis and Instrumentation, APH Publishing Corporation, NewDelhi.

Ramakrishnan, S. 1998. Groundwater, TNHB Colony, Tamil nadu.

Ramsden, E. N. 1996. Chemistry of the Environment, Stanley Thornes Publications Ltd, Cheltenham.

Richard, L.A. 1954. Diagnosis and Improvement of saline and alkali soil, U.S.Department of Agriculture Handbook, No.60, pp.160.

Sawyer, C. N. McCarty, P. L., and Parkin, G. F., 2003. Chemistry for Environmental Engineering, Mc Graw Hill, Inc, New York.

Schivanna 2008. Isotopic techniques for groundwater contamination studies, Hand book for wokshop on isotope tracer techniques for water resources development and management, CWRDM, Kerala, pp:103-110.

Schoeller, H. 1977. Geochemistry of Groundwater. In: Groundwater Studies-An International Guide for Research and practise. UNESCO, Paris, pp.1-18.

Saxena, M. M. 1998. Environmental Analysis: Air, Water and Soil, Agrobotanica, Bikaner.

Sharma, B. K. and Kaur, H. 1996. An Introduction to Environmental Pollution, Goel Publishing House, Meerut, p.512.

Sheet, M. H. 2012. Sewage water irrigation effects on groundwater quality in Semel Area (IRAQ), ARPN Journal of Engineering and Applied Sciences, 7(8):971974.

Sial, J. K., Bibi, S., and Qureshi, A. S. 2005. Environmental impacts on sewage irrigation on Groundwater quality. Pakistan Journal of Water Resources, 9(1): 49-53.

Trivedi, R. K., and Goel, P. K. 1986. Chemical and biological methods for water pollution studies, Environmental Publications, Karad, India.

Todd, D. K. 2001. Groundwater Hydrology. John Wiley and Sons Publication, Canada.

UNEP 1999. United Nations Environment Program, Global Environment Outlook 2000.UK: Earthscan.

US Salinity Laboratory Staff 1954. Diagnosis and improvement of saline and alkali soils, US Department of Agricultural soils, US Department of Agricultural Hand Book 60, Washington.

Varghese, J. and Jaya, D.S. 2009. Assessment of the bacteriological quality of groundwater around the sewage farm in Muttathara-Valiathura area, Thiruvananthapuram district. Indian Journal of Environmental Protection, 29 (5): 430-434.

Venkateswarlu, K. S. 1996. Water Chemistry: Industrial and Power Stations Water Treatment, New Age International (P) Limited Publishers, New Delhi.

Wilcox, L.V. 1948. The quality of water for irrigation use, US Department of Agricultural Technical Bulletin 1962, Washington DC.

WHO 1994. Guidelines for drinking water quality, Recommendations, Geneva.

WHO 2003. Ammonia in drinking water, Background document for development of WHO Guidelines for drinking water quality.

WHO 2011. Nitrite and Nitrate in drinking water, Background document for development of WHO Guidelines for drinking water quality. 